\title{
Językowe aspekty polskiej polityki naukowej: pomiędzy lokalnością a globalizacją informacji
}

\author{
Piotr Nowak \\ Instytut Językoznawstwa, Zaktad Infolingwistyki \\ Wydziat Neofilologii \\ Uniwersytet im. Adama Mickiewicza w Poznaniu
}

\begin{abstract}
Abstrakt
Cel/teza: Udowodnienie tezy, że na polską politykę językową w istotny sposób wpływają instytucje kreujące politykę naukową.

Koncepcja/metody badań: Konfrontacja założeń polityki językowej władz polskich wyrażonej w Konstytucji RP oraz Ustawie o języku polskim z aktami prawnymi wydanymi przez instytucje odpowiedzialne za polską politykę naukową.

Wyniki i wnioski: W założeniach polityki naukowej widoczny jest brak dbałości o przestrzeganie ducha Ustawy o języku polskim, choć jest ona zgodna z jej literą. Duch tej ustawy - wyrażony przede wszystkim w jej uroczystej preambule - kłóci się z nakłanianiem środowisk akademickich w Polsce do publikowania swego dorobku w językach obcych - przede wszystkim w języku angielskim.

Oryginalność/wartość poznawcza: Zarówno w literaturze informatologicznej, jak i językoznawczej dotychczas rzadko podejmowano problematykę kreowania polityki językowej przez instytucje odpowiedzialne za politykę naukową.
\end{abstract}

\section{Słowa kluczowe}

Planowanie języka. Polityka językowa. Polityka naukowa. Nauka o informacji.

Otrzymany: 13.12.2014. Poprawiony: 27.02.2015. Zaakceptowany: 9.03.2015.

\section{Wprowadzenie. Ustawowe założenia polskiej polityki językowej na tle prawnej ochrony języków w Europie}

Szybko postępujące procesy globalizacyjne spowodowały, że wiele państw europejskich podjęło kroki zmierzające do prawnej ochrony swych języków narodowych. Zdecydowały się na to m.in.: Białoruś, Francja, Litwa, Łotwa, Macedonia, Mołdawia, Słowacja, Słowenia, Ukraina, Węgry a także Polska. W tym samym kierunku zmierza ustawodawstwo Unii Europejskiej, która gwarantuje swym obywatelom możliwość kontaktu z własnymi agendami w ich językach narodowych.

W praktyce w poszczególnych krajach ochrona języka przyjmuje różną postać. Ustawa przyjęta przez parlament węgierski nie stwierdza wprost na czym ochrona ta ma polegać, będąc jedynie oficjalną deklaracją konieczności jej podjęcia (Bańczerowski, 2011, 67). Zupełnie inaczej sprawa ta wygląda w przypadku języka słowackiego, którego ochrona, znajdując swe obywatelstwo zarówno w konstytucji, jak i w specjalnej ustawie, zawiera bardzo precyzyjne rozwiązania prawne oraz możliwość penalizacji w przypadku ich łamania (Lisek, 2011). 
Dyskusja nad planową polityką językową, wówczas przede wszystkim jako zagadnieniem badawczym, a nie problemem społeczno-politycznym, rozpoczęła się w Polsce stosunkowo późno, bo zajmować się nią zaczęto dopiero w latach 70. ubiegłego wieku (Lubaś, 1977). Na ustawowe rozstrzygnięcia w tym zakresie czekaliśmy aż do transformacji ustrojowej w latach 90. Najważniejsze z nich pojawiają się w dwóch fundamentalnych aktach prawnych: Konstytucji Rzeczypospolitej Polskiej (1997) oraz Ustawie o języku polskim (1999). Polską politykę językową klasyfikuje się jako „politykę dowartościowania języka urzędowego, która uprzywilejowuje jeden język" (Pisarek, 2008, 83). Standardowo, podobnie jak to ma miejsce w ustawodawstwie innych państw, realizowana jest ona zarówno w zakresie statusu języka, jak i jego korpusu (Wiertlewski, 2011).

Uchwalona w 1997 r. Konstytucja RP była pierwszą polską ustawą zasadniczą, gwarantującą językowi polskiemu ochronę prawną (żadna wcześniejsza Konstytucja nie chroniła prawnie języka polskiego). Gwarancja ta została udzielona przede wszystkim w art. 27, któremu nadano brzmienie (Konstytucja, 1997):

W Rzeczypospolitej Polskiej językiem urzędowym jest język polski.

Ustawa o języku polskim uchwalona została w dwa lata później, dodatkowo normując prawną ochronę języka w bardzo konkretny, szczegółowy sposób. Poprzedzono ją uroczyście brzmiącą preambułą, w której traktuje się język polski jako (Ustawa, 1999)

podstawowy element narodowej tożsamości,

dobro narodowej kultury,

narzędzie ochrony tożsamości narodowej w procesie globalizacji.

W tym kontekście twórcy Ustawy powołują się na „doświadczenie historii, kiedy walka zaborców i okupantów z językiem polskim była narzędziem wynaradawiania”.

Co ważne, z punktu widzenia problematyki poruszanej w tym artykule, w ustawie mówi się wprost o konieczności ochrony języka polskiego przed wypieraniem go z dużych obszarów komunikacji przez inne języki (głównie język angielski) - zostało to zapisane w art.1. $\mathrm{Z}$ drugiej natomiast strony, jeden z największych obszarów komunikacji pisanej, z jakim mamy do czynienia - czyli twórczość naukową - wyklucza się z tego przepisu. W art. 11 pojawia się bowiem zastrzeżenie, zgodnie z którym najważniejsze regulacje prawne zawarte w Ustawie o języku polskim nie dotyczą

działalności dydaktycznej i naukowej szkół wyższych [...], działalności naukowej w jednostkach naukowych [...], twórczości naukowej i artystycznej [sic! - PN].

Podobnie jak to ma miejsce w innych krajach, w praktyce polityka językowa RP jest wielopodmiotowa; kształtują ją różne instytucje państwowe oraz organizacje społeczne - Sejm RP, ministerstwa, samorządy, mass-media, Kościół katolicki etc. Wpływ poszczególnych podmiotów na faktyczną realizację polskiej polityki językowej opisywany był w literaturze wielokrotnie (por. np. Wiertlewski, 2011).

Przedmiotem naszych rozważań stanie się grupa instytucji tworzących politykę naukową w Polsce, która - jak się okazuje - odgrywa także istotną rolę w zakresie polityki językowej. 
W aktach normatywnych, które wydają, poszukiwać będziemy rozwiązań systemowych dotyczących języka, ze szczególnym uwzględnieniem konsekwencji wynikających ze stosowania języka polskiego lub obcego w obiegu dokumentów urzędowych oraz języka, w jakim publikowane są źródła informacji wytwarzane przez polską naukę.

\section{Ministerstwo Nauki i Szkolnictwa Wyższego wraz z jego agendami jako podmiot polskiej polityki naukowej}

Od 2006 r. interesującym nas obszarem działalności państwa zajmuje się Ministerstwo Nauki i Szkolnictwa Wyższego. Śledząc ewolucję tego resortu w ciągu ostatniego dziesięciolecia, należy zaznaczyć, że jego struktura organizacyjna (oraz nazwa) kilkakrotnie uległa zmianie. Zostało ono przekształcone z Ministerstwa Edukacji i Nauki (powołanego w 2005 r.); wcześniej resort ten nosił nazwę Ministerstwa Nauki i Informatyzacji (od 2004 r.).

Na mocy ustawy z 30 kwietnia 2010 r. powołano Narodowe Centrum Nauki - pomocniczy organ ministra nauki i szkolnictwa wyższego, do którego zadań należy rozdział funduszy na badania naukowe (Ustawa, 2010). W okresie poprzedzającym powstanie NCN, w latach 2005-2010, przy ministrze nauki i szkolnictwa wyższego działała Rada Nauki - pochodzący z wyboru organ składający się z uczonych reprezentujący różne dziedziny, której zadania częściowo pokrywały się z misją NCN. Kompetencje Rady Nauki były jednak bardziej ograniczone (miała niewielki wpływ na decyzje podejmowane przez ministra), choć jej działalność środowiska naukowe oceniały raczej pozytywnie. Przed rokiem 2005 organem, który pełnił funkcję dwóch wspomnianych wyżej instytucji (NCN oraz Rady Nauki), był Komitet Badań Naukowych - instytucja odpowiedzialna za kształtowanie polityki naukowej państwa od momentu powołania w 1991 r. do chwili przekształcenia jej w 2005 r. w Radę Nauki. Przed Komitetem postawiono zadanie koordynowania polityki naukowej w Polsce zgodnie ze standardami międzynarodowymi.

Ustawodawca, delegując część kompetencji w zakresie polityki naukowej, bądź sam minister, delegując część swych własnych kompetencji, powołali ponadto szereg kolejnych instytucji współuczestniczących w kształtowaniu polityki naukowej. Należą do nich m.in.:

- Komisja Ewaluacji Jednostek Naukowych - organ opiniodawczo-doradczy ministra, do którego obowiązków należy ustalanie zasad stratyfikacji instytucji naukowych i, na tej podstawie, okresowa ich ocena (MNiSW, 2015a).

- Rada Główna Nauki i Szkolnictwa Wyższego, która funkcjonuje jako wybieralny organ przedstawicielski nauki i szkolnictwa wyższego (RGNiSW, b.d). http://www. rgnisw.nauka.gov.pl/).

- Narodowy Program Rozwoju Humanistyki (utworzony przez ministra nauki i szkolnictwa wyższego 8 listopada 2010), który ma wspierać badania humanistyczne „o zasadniczym znaczeniu dla zachowania polskiej tożsamości narodowej”. Przed NPRH postawiono także zadanie upowszechniania dorobku polskiej humanistyki na świecie (NPRH, 2015b).

- Tzw. zespoły ministra, będące doraźnymi ciałami, które powoływane są przez MNiSW do konkretnych zadań. Nas interesować będzie przede wszystkim „Zespół specjalistyczny do oceny czasopism naukowych dla potrzeb przyszłej oceny parametrycznej 
i sporządzenia wykazu wybranych czasopism naukowych" (powołany zarządzeniem MNiSW z dnia 28 marca 2012 (Zarządzenie, 2012).

- Komitet Polityki Naukowej, do którego zadań należy współpraca z ministrem przy opracowywaniu dokumentów (MNiSW, 2015b):

dotyczących rozwoju nauki oraz polityki naukowej i innowacyjnej, projektu budżetu państwa oraz planu finansowego określającego środki finansowe na naukę, krajowych i zagranicznych priorytetów inwestycyjnych.

Ponadto opiniowanie:

projektów aktów normatywnych dotyczących rozwoju nauki i innowacyjności, planów działalności NCN i NCBR oraz sporządzanie merytorycznych ocen sprawozdań z ich działalności.

\section{Językowe aspekty polityki naukowej}

Przyjrzyjmy się nieco bliżej wybranym aktom normatywnym, wydanym w minionej dekadzie przez wspomniane instytucje, których treść bezpośrednio lub pośrednio kreowała politykę językową w obszarze polskiej nauki oraz szkolnictwa wyższego.

\subsection{Komitet Badań Naukowych}

Spośród wszystkich wymienionych wyżej instytucji KBN funkcjonował najdłużej. Oczywiście, zarządzenia i inne akty prawne, które wydawał, pośrednio także dotyczyły polityki językowej, a rozstrzygnięcia pojawiające się w latach 90. ubiegłego wieku w treści wydawanych przez KBN rozporządzeń, zapoczątkowały dyskusję nad znaczeniem języka w komunikacji naukowej w Polsce. Zasadniczym problemem związanym z polityką językową, jaki próbowano wówczas rozwiązać i który, notabene, nie stracił nic ze swej aktualności do chwili obecnej, było powiązanie wartości źródła informacji z językiem jego wydania. Już wówczas bardzo wyraźnie optowano za premiowaniem twórczości naukowej (bez względu na dyscyplinę, jaką reprezentowała), publikowaną w niektórych językach obcych. W 1999 r., w odniesieniu do nauk humanistycznych, KBN wydał Zalecenia w zakresie oceny piśmiennictwa naukowego (w dokumencie zatytułowanym Szczególne zasady i definicje oceny parametrycznej jednostek naukowych i jednostek badawczo-rozwojowych; Zespół Nauk Humanistycznych H-01), wprowadzając dwie kategorie publikacji: (1) publikacje o zasięgu krajowym oraz (2) publikacje o zasięgu międzynarodowym. Kryterium, które zastosowano w tym podziale, stanowił język, a nie miejsce wydania (lub inne kryteria formalne). W Zaleceniach czytamy (KBN, 1999):

Zasięg publikacji określany jest przez język, w którym została wydrukowana: zasięg międzynarodowy oznacza języki kongresowe - angielski, francuski, niemiecki, hiszpański i rosyjski - zasięg krajowy oznacza język polski oraz pozostałe języki niekongresowe (...). 


\subsection{Narodowe Centrum Nauki}

W ustawie powołującej NCN pojawił się szczegółowy zapis określający językowy modus operandi praktycznych aspektów jej funkcjonowania. Mianowicie w artykule 29 wprowadza się obowiązek składania wniosków o finansowanie projektów badawczych w języku polskim i angielskim, z zastrzeżeniem, że:

Rada może wskazać dziedziny lub dyscypliny nauki, w których wnioski składa się tylko w języku polskim (Ustawa, 2010).

W kontekście tego przepisu pojawia się oczywiście pytanie, dlaczego wymagane jest składanie wniosków w obu językach, a nie na przykład wyłącznie w języku polskim lub tylko w języku angielskim (w obu językach formularze aplikacyjne mają identyczną postać). Niektórzy z analityków polskiej polityki językowej uważają to za ograniczoną promocję bilingwizmu (zob. np. Wiertlewski, 2011). NCN nie jest jednak konsekwentne w jego promowaniu, ponieważ w Zarządzeniach Dyrektora Centrum w sprawie określenia szczegółowego trybu sporządzania ocen wniosków przez Zespoły Ekspertów (ostatnie, do jakiego dotarł autor tego tekstu, nosi numer 32/2013 i wydane zostało 16 września 2013 r.) dopuszcza się rozmowę z wnioskodawcą aplikującym o grant, która (NCN, 2013) przeprowadzana jest w siedzibie Centrum i odbywa się w języku polskim.

Trudno orzec, dlaczego $\mathrm{w}$ tym przypadku pozbawia się zainteresowanych przedstawienia swych argumentów w języku angielskim!? W kontekście języków, w których składa się wnioski, powinno być to możliwe.

\subsection{Narodowy Program Rozwoju Humanistyki}

Zadania NPRH ujęte zostały w modułach; problem języka pojawia się w module trzecim (Modut upowszechniajacy wyniki polskich badań humanistycznych na świecie), w którym mówi się o grantach dotyczących (NPHR, 2015a):

finansowania tłumaczeń i publikacji dzieł o najwyższym poziomie naukowym i doniosłości merytorycznej w celu zapewnienia im wysokiej pozycji naukowej oraz szerszej dostępności zarówno dla naukowców polskich i zagranicznych

oraz

wspierania elektronicznych wydań najważniejszych czasopism polskiej humanistyki w innych wersjach językowych (w szczególności w języku angielskim).

\subsection{Zespót ds. oceny czasopism naukowych}

Z uwagi na znaczenie czasopisma naukowego w procesie ewaluacji badaczy i - pośrednio - oceny jednostek naukowo-badawczych, ewentualne pojawienie się w dokumentach wydawanych przez Zespół zagadnień wiążących się z językiem będzie niezwykle istotne. W obowiązującym w chwili obecnej rozporządzeniu Ministra Nauki i Szkolnictwa 
Wyższego z 13 lipca 2012 r. w sprawie kryteriów i trybu przyznawania kategorii jednostkom naukowym (Rozporządzenie, 2012) znajdują się ramowe zasady tworzenia rankingu polskich czasopism naukowych. W rozporządzeniu zakłada się tworzenie trzech list czasopism: listy A (zagranicznych i polskich z JCR; posiadających Impact Factor - najwyżej punktowanych), liście B (polskich nieposiadających Impact Factor; punktowanych od 1 do 10 punktów) oraz C (polskich rejestrowanych w bazie ERIH - The European Reference Index for the Humanities) - wszystkim czasopismom figurującym na tej liście nadaje się minimum 10 punktów. W tym kontekście w Rozporządzeniu wprowadza się kategorię „poziomu umiędzynarodowienia” czasopisma, definiując go m.in. na podstawie języka publikacji zamieszczonych w nim artykułów (\$ 14.1-4).

Jak jednak traktować artykuły w czasopismach, które nie spełniają dość rygorystycznych kryteriów narzucanych przez Zespół je oceniający i nie zakwalifikują się do wspomnianej powyżej ministerialnej listy czasopism punktowanych? Kwestię tę częściowo zdają się rozstrzygać kolejne dwa punkty cytowanego powyżej paragrafu 14, korespondujące z problematyką polityki językowej w kontekście polityki wydawniczej w sferze nauki. Otóż zakłada się, że w ocenie jednostki można brać pod uwagę artykuły, które ukazały się w

zagranicznym czasopiśmie naukowym [...] w języku podstawowym w danej dyscyplinie naukowej lub w językach: angielskim, niemieckim, francuskim, hiszpańskim, rosyjskim lub włoskim.

(Dlaczego właśnie tych?) Oznacza to tyle, że na podstawie tego przepisu artykuł polskiego humanisty, opublikowany w niepolskim czasopiśmie niemającym IF i wydawanym w języku chińskim lub arabskim (nikogo nie trzeba przekonywać, że to języki o zdecydowanie większej liczbie użytkowników niż na przykład język włoski, który pojawia się w rozporządzeniu), nie będzie brany pod uwagę jako dorobek naukowy jednostki i nie wpłynie na jej ocenę. Ustawodawca pozostawia sobie wprawdzie furtkę w kolejnym fragmencie tego paragrafu, stwierdzając, że

właściwa komisja Komitetu [Ewaluacji Jednostek Naukowych] decyduje, na wniosek zespołu ewaluacji, o którym mowa w art. 43 ust. 1 ustawy, o uznaniu języka innego niż języki: angielski, niemiecki, francuski, hiszpański, rosyjski lub włoski za język podstawowy w danej dyscyplinie naukowej.

Zastrzega jednak, że dotyczy to dwóch dyscyplin filologicznych:

w szczególności w zakresie dyscyplin naukowych językoznawstwo i literaturoznawstwo.

Nie bardzo wiadomo jednak, jak interpretować stwierdzenie „w szczególności”? Czy można listę tych dyscyplin poszerzyć o kolejne, czy prace niefilologiczne opublikowane w innym języku niż wymienione w Rozporządzeniu z definicji nie mogą wchodzić w zakres dorobku naukowego jednostki?

Tyle na temat wykładni prawnej działań ministerialnego Zespołu ds. oceny czasopism naukowych. Zadaniem natomiast samego Zespołu jest ustalenie na jej podstawie praktycznych zasad ewaluacji czasopism, w których publikują polscy uczeni. Najważniejszym dokumentem wydanym przez Zespół jest Komunikat w sprawie kryteriów i trybu oceny czasopism naukowych (obowiązujący obecnie został wydany 4 września 2012 r.). Należy 
przede wszystkim zwrócić uwagę na fakt, że nie pojawia się w nim (jak to miało miejsce w rozporządzeniach KBN-u) pojęcie „poziomu umiędzynarodowienia” czasopisma. W zamian operuje się terminem ,język publikacji”, definiując go jako

procentowy udział artykułów naukowych opublikowanych w pełnej wersji w języku angielskim, francuskim, hiszpańskim, niemieckim, rosyjskim, lub włoskim w stosunku do ogólnej liczby opublikowanych artykułów naukowych (MNiSW, 2012).

Podniesienie oceny punktowej czasopisma zależy od odsetka artykułów opublikowanych w tych językach, natomiast próg, powyżej którego tak się dzieje, zależy od dziedziny, w ramach której ukazuje się czasopismo. W przypadku, gdy zostaje on przekroczony, ocena czasopisma jest automatycznie podnoszona.

Nie wdając się w szczegóły tej metodyki, wyraźnie widać, że premiowane są czasopisma wydawane we wspomnianych językach obcych. Periodyki publikujące wyłącznie w języku polskim z definicji zawartej w Kryteriach oceny czasopism uzyskują niższą ocenę niż te, które publikują artykuły w wyszczególnionych w tym dokumencie językach. W kontekście podanych wcześniej przykładów postponowania języka polskiego raczej to nie dziwi, niemniej trudno zorientować się, dlaczego nie wyróżnia się języka angielskiego, traktując go na równi z kilkoma innymi językami europejskimi. Język angielski funkcjonuje przecież nie od dziś w roli współczesnej lingua franca i jego znaczenie jako narzędzia komunikacji jest nieporównanie większe od roli, jaką w globalnej komunikacji naukowej pełnią pozostałe $\mathrm{z}$ wymienionych.

\section{Język publikacji naukowej a "sprawa polska”}

W Polsce, przede wszystkim z uwagi na uwarunkowania historyczne, do sprawy języka podchodzi się niezwykle emocjonalnie, czego dowodem może być choćby cytowana na początku artykułu preambuła Ustawy o języku polskim. Niektóre krajowe środowiska akademickie są bardzo uczulone na łamanie przepisów tej ustawy. Z pewnością należą do nich humaniści, choć w pewnym zakresie także kręgi akademickie skupiające reprezentantów innych środowisk, niekoniecznie humanistycznych. Każdy przypadek niedowartościowania języka polskiego wywołuje dyskusję nad polityką językową prowadzoną w Polsce. Jaskrawo problem ten postawiony został w 2008 r. przez Radę Języka Polskiego, która zaprotestowała przeciwko nierównemu traktowaniu języków polskiego i angielskiego w projekcie karty oceny jednostki naukowej w dziedzinie nauk humanistycznych i społecznych. Dnia 28 maja 2008 r. Rada wystosowała w tej sprawie list do kierownictwa MNiSW. W stanowisku Rady stwierdzono (RJP, 2008):

Proponowane $\mathrm{w}$ [projekcie karty oceny jednostki naukowej w dziedzinie nauk humanistycznych i społecznych - PN] przyznawanie zdecydowanie większej liczby punktów za publikacje naukowe w języku angielskim niż w języku polskim, mające racjonalne podstawy w przypadku nauk ścisłych i technicznych, jest absolutnie nie do przyjęcia w filologii polskiej. Jest rzeczą naturalną, że monografie i artykuły naukowe, a także np. podręczniki i słowniki powstające w Polsce i dotyczące języka polskiego, są pisane po polsku. Uzasadnianie tego jest zbędne i aż dziwne, że autorzy projektu rozporządzenia tego nie dostrzegli. Przypomnę, że Ustawa o języku polskim w art. 3. p. 1 stanowi, 
że „Ochrona języka polskiego polega w szczególności na: dbaniu o poprawne używanie języka i doskonaleniu sprawności językowej jego użytkowników oraz na stwarzaniu warunków do właściwego rozwoju języka jako narzędzia międzyludzkiej komunikacji”, a także, że „Do ochrony języka polskiego są obowiązane wszystkie organy władzy publicznej oraz instytucje i organizacje uczestniczące w życiu publicznym". [...] projekt [...] narusza w tym punkcie wspomnianą ustawę przez preferowanie języka angielskiego kosztem języka polskiego - ojczystego, w publikacjach naukowych dotyczących tegoż języka ojczystego i literatury ojczystej. Gdyby pracownicy naukowi mieli się stosować do przewidywanych w projekcie rozwiązań, powinni pisać rozprawy z zakresu literatury polskiej - po angielsku, a słowniki, np. ortograficzny, frazeologiczny, czy wreszcie słowniki języka polskiego lub poprawnej polszczyzny też powinny powstawać w języku angielskim(!).

„Absurdalność takiej sytuacji jest aż nadto widoczna” - stwierdza się w konkluzji tego protestu (RPJ, 2008).

Kilka lat później śladem Rady Języka Polskiego poszedł Zarząd Główny Towarzystwa Kultury Języka, wyrażając w piśmie kierowanym do prezydenta RP Bronisława Komorowskiego

[...] stanowczy protest przeciwko proponowanym przez Ministerstwo Nauki i Szkolnictwa Wyższego i jego agendy zasadom oceny jednostek naukowych, czasopism naukowych i publikacji naukowych według kryterium języka [...].

Przeciwstawiano się oczywiście przypisywaniu językowi polskiemu (Uchwała, 2012)

niższej rangi niż językowi angielskiemu (lub językom kongresowym).

Rzecz jasna, zacytowane powyżej głosy w sprawie językowych aspektów polityki naukowej, są tylko małym fragmentem dyskusji prowadzonej na ten temat w ostatnim czasie w Polsce. Stanowisko Rady Języka Polskiego dotyczyło kwestii fundamentalnych, które wypływają z treści samej ustawy o języku, natomiast jednostki naukowe zainteresowane były praktycznymi konsekwencjami traktowania takiego lub innego języka jako wartości lub antywartości, najczęściej w kontekście kryteriów ich oceny, czyli uzyskanej kategorii i, co za tym idzie, skalą otrzymywanych dotacji ${ }^{1}$. Nietrudno się zatem domyślić, że w tym wypadku najczęściej protestowały rady wydziałów poszczególnych uczelni niezadowolone otrzymaną kategorią lub (co również nie należało do rzadkości) zmianą oceny wydawanych przez siebie czasopism, próbując w ten sposób wymóc na MNiSW rewizję stosowanych kryteriów oceny, by ją podwyższyć w następnej ewaluacji. Tak oto otrzymujemy kolejny podmiot działający w obszarze nauki i szkolnictwa wyższego, który kształtuje polską politykę językową - są nimi rady wydziałów uczelni wyższych.

W krótkiej formie wypowiedzi, jaką jest artykuł, trudno przedstawić choćby niewielką część protestów rad wydziałów humanistycznych w sprawie interesujących nas w tej chwili zagadnień. Niemniej ich treść w dużym stopniu się pokrywa - wydziały, których dorobek powstaje przede wszystkim w języku polskim, postulują jego dowartościowanie; przeciwne stanowisko zajmują rady wydziałów, których pracownicy publikują głównie w innych językach niż polski. O ile poloniści zawsze optowali (i optują) za co najmniej

1 W Polsce możliwe jest uzyskanie jednej z czterech kategorii: A+, A, B oraz C; Wydziały kategoryzowane są m.in. przez ocenę dorobku naukowego ich pracowników, ten zaś uzależniony jest m.in. od liczby punktów uzyskiwanych przez publikacje ich autorstwa - w zależności od języka ich wydania ocena może być różna. 
równym traktowaniem języka polskiego z innymi językami, to neofilolodzy akcentowali w swych protestach konieczność dowartościowania także innych języków. W proteście Rady Wydziału Neofilologii Uniwersytetu im. Adama Mickiewicza w Poznaniu z 24 października 2005 r. skierowanym do ówczesnego Ministra Nauki i Informatyzacji czytamy (UAM, 2005):

[...] Czym gorsze są tzw. języki kongresowe (francuski, niemiecki, rosyjski), czy języki oficjalnie używane w ONZ od języka polskiego czy angielskiego?

Mniej liczne, choć równie ciekawe, są inne argumenty podnoszone przez rady. Dla przykładu można zacytować w tym kontekście Stanowisko Rady Wydziału Historycznego Uniwersytetu Warszawskiego w sprawie kompleksowej oceny jednostki naukowej za lata 2009-2012, która krytykuje niezdefiniowane pojęcia „język podstawowy” oraz zastanawia się (UW, 2013)

czy wobec przyjęcia Ustawy o ochronie języka polskiego, narzucone przez rozporządzenie narzędzie do sporządzania wykazu cytowań powinno być dostępne jedynie w języku angielskim [prawdopodobnie chodzi o usługę „Publish or Perish” - PN].

Z kolei Rada Wydziału Filologii Polskiej i Klasycznej Uniwersytetu im. Adama Mickiewicza w Poznaniu krytykuje (UAM, 2013):

nadanie językowi dokumentów odnoszących się do nauki i szkolnictwa wyższego, zwłaszcza używanemu w opisach Krajowych Ram Kwalifikacji i - co za tym idzie - opisach tzw. efektów kształcenia, postaci przyjaznej obywatelowi, zrozumiałej i pozbawionej efektów nowomowy.

Także w środowisku Polskiej Akademii Nauk szeroko dyskutowano kwestie prowadzonej w kontekście polityki naukowej polityki językowej w Polsce. Na wspólnym posiedzeniu przewodniczących Komitetów Naukowych Wydziału I Nauk Humanistycznych i Społecznych PAN pojawiły się nawet wątki quasi-patriotyczne - omawiając protest Komitetów Naukowych PAN przeciwko dewaluacji nauki, na prowadzonym przez siebie blogu prof. Bogusław Śliwerski napisał:

\footnotetext{
Wymuszanie publikowania w języku angielskim - czytamy w protokole z tego posiedzenia - sprawia, że wpisujemy się w naukową politykę kolonialną. Jest w tym ukryty program - że to, co polskie jest gorsze, drugorzędne, a to co anglo-amerykańskie jest światowe (Śliwerski, 2013).
}

\section{Wnioski}

Staraliśmy się udowodnić, że instytucje, przed którymi stawia się zadania związane z planowaniem i wdrażaniem polityki naukowej, oddziałują także na kształt polityki językowej państwa. Zebrane powyżej fakty dowodzą, że oddziaływanie to ma miejsce zarówno w obszarze planowania polityki językowej, jej normalizowania, jak również praktycznej realizacji. Można z nich wywnioskować, że: 
- oddziaływanie to ma różny charakter i zakres - w pewnych obszarach jest jednak na tyle wyraźne, że można mówić o istotnym wpływie podmiotów kształtujących politykę naukową na politykę językową;

- w niektórych aktach prawnych dotyczących polityki naukowej widoczny jest brak dbałości o przestrzeganie fundamentalnych zasad zawartych w preambule Ustawy o języku polskim;

- w kilku wypadkach w realizowanej w Polsce polityce naukowej rozwiązania dotyczące języka są sprzeczne z regulacjami zawartymi w Ustawie;

- pewne rozporządzenia regulujące kwestie języka w polityce naukowej trudno racjonalnie uzasadnić.

Mając na uwadze ostatni ze sformułowanych wniosków, wróćmy na koniec jeszcze na chwilę do Ustawy o języku polskim, konkretnie jej preambuły. Jak wiemy, mówi się w niej o „konieczności ochrony tożsamości narodowej w procesie globalizacji”, zakładając, że język jest niezbędnym elementem tej tożsamości. Należy jednak pamiętać, że procesy globalizacyjne zawierają już w swej definicji tzw. ryzyko nierówności. Powszechnie wiadomo, że nauka funkcjonuje w kontekście globalnym. A zatem m.in. poprzez twórczość naukową można chronić „tożsamość narodową w procesie globalizacji”. Prawdopodobnie jednak nie da się tego skutecznie robić, nie używając języka angielskiego - ergo być może optyka postrzegania walki o miejsce kultury polskiej w globalnej mozaice kulturowej za pomocą języka polskiego jest błędna?! W dyskusji nad językowymi aspektami polityki naukowej w Polsce podnosi się także inną, bardziej przyziemną, lecz z pewnością równie ważną, kwestię, jaką jest wyrażanie dorobku polskiej humanistyki w rodzimym języku. Fakt, że humaniści głównie publikują w języku polskim, może decydować o ich marginalizacji w dostępie do międzynarodowych grantów badawczych. Opiniodawcy takich wniosków zupełnie nie znają aplikujących o nie Polaków, bowiem ci ostatni nie publikują w obiegu międzynarodowym (Trzcionowski, 2014). Typowy przykład sytuacji bez wyjścia? Z pewnością rozstrzygnięcie kwestii, w jakim języku publikować dorobek polskiej humanistyki, w każdym razie w chwili obecnej, nie wydaje się łatwe. Wręcz przeciwnie - prawdopodobnie nie jest w ogóle w sensie racjonalnym możliwe. Dlatego autor nie kończy swych rozważań żadnym bardziej kategorycznym wnioskiem, licząc jednak, że także środowisko polskich informatologów szerzej włączy się do dyskusji na temat polityki językowej realizowanej w kraju.

\section{Bibliografia}

Bańczerowski, J. C. (2011). Kilka uwag o prawnej ochronie języka polskiego i węgierskiego. Język. Komunikacja. Informacja, 6, 63-70.

KBN (1999). Komitet Badań Naukowych. Zespół Nauk Humanistycznych (H01) [online]. Szczególne zasady i definicje oceny parametrycznej jednostek naukowych $i$ jednostek badawczo-rozwojowych [27.02.2015], http://kbn.icm.edu.pl/finauki98/system/ost/ost_h01.html

Konstytucja (1997). Konstytucja Rzeczypospolitej Polskiej z dnia 2 kwietnia 1997. Dz. U., Nr 78, poz. 483.

Lisek, G. (2011). Polityka językowa Polski i jej sąsiadów na przykładzie Republiki Czeskiej i Republiki Słowackiej. Język. Komunikacja. Informacja, 6, 79-89.

Lubaś, W. red. (1977). Socjolingwistyka 1. Polityka językowa. Katowice: Wydaw. UŚ.

MNiSW (2012). Ministerstwo Nauki i Szkolnictwa Wyższego [online]. Komunikat Ministra Nauki i Szkolnictwa Wyższego w sprawie kryteriów i trybu oceny czasopism naukowych [27.02.2015], 
www.nauka.gov.pl/komunikaty/komunikat-ministra-nauki-i-szkolnictwa-wyzszego-w-sprawiekryteriow-i-trybu-oceny-czasopism-naukowych_31365.html

MNiSW (2015a). Ministerstwo Nauki i Szkolnictwa Wyższego [online]. Komitet Ewaluacji Jednostek Naukowych [27.02.2015], http://www.nauka.gov.pl/komitet-ewaluacji-jednostek-naukowych-main/ MNiSW (2015b). Ministerstwo Nauki i Szkolnictwa Wyższego [online]. Komitet Polityki Naukowej [27.02.2015], http://www.nauka.gov.pl/komitet-polityki-naukowej-nauka

NCN (2013). Narodowe Centrum Nauki [online]. Zarządzenie Nr 32/2013 Dyrektora Narodowego Centrum Nauki z dnia 16 września 2013 r. w sprawie określenie szczegółowego trybu sporządzania ocen wniosków przez zespoły ekspertów [27.02.2015], http://www.ncn.gov.pl/sites/default/files/ pliki/zarzadzenia-dyrektora/zarzadzenieDyr-32_2013.pdf

NPRH (2015a). Narodowy Program Rozwoju Humanistyki [online], [27.02.2015], http://www.nauka. gov.pl/narodowy-program-rozwoju-humanistyki/

NPRH (2015b). Narodowy Program Rozwoju Humanistyki [online]. Zdobywamy granty na badania [27.02.2015], http://www.granty-na-badania.com/p/narodowy-program-rozwoju-humanistyki.html

Pisarek, W. (2008). Polityka językowa w wybranych krajach europejskich. W: J. Warchala, D. Krzyżyk (red.), Polska polityka językowa w Unii Europejskiej. Katowice: Wydaw. UŚ, s. 79-105.

RGNiSW (b.d.). Rada Główna Nauki i Szkolnictwa Wyższego [online], [27.02.20155], http://www. rgnisw.nauka.gov.pl

RJP (2008). Interwencja w sprawie punktacji za prace naukowe [online]. Rada Języka Polskiego [27.02.2015], http://www.rjp.pan.pl/index.php?option=com_content\&view=article\&id=106:interwencja-w-sprawie-punktacji-za-prace-naukowe\&catid=46:interwencje-rady

Rozporządzenie (2012). Rozporządzenie Ministra Nauki i Szkolnictwa Wyższego z 13 lipca 2012 roku w sprawie kryteriów i trybu przyznawania kategorii jednostkom naukowym. Dz. U., poz. 877.

Śliwerski, B. (2013). Protest Komitetów Naukowych PAN przeciwko dewaluacji nauki [online]. Pedagog [27.02.2015], http://sliwerski-pedagog.blogspot.com/2013/02/protest-komitetow-naukowych-pan.html

Trzcionowski, L. (2014) Polemicznie o uczelniach i niedawnych publikacjach na ich temat, http:// obywatelenauki.pl/2014/03/lech-trzcionkowski-polemicznie-o-uczelniach-i-niedawnychpublikacjach-na-ich-temat

UAM (2005). List dziekana Wydziału Neofilologii UAM prof. dra hab. Józefa Darskiego do ministra nauki i informatyzacji prof. dra hab. Michała Kleibera z 24.10.2005 r. [brak nagłówka, dok. niepubl.].

UAM (2013). Uchwała w sprawie: wsparcia protestu środowiska akademickiego przeciwko parametryzacji i biurokratyzacji nauki i poparcia Uchwały przekazanej przez Wydział Polonistyki Uniwersytetu Jagiellońskiego. Uniwersytet im. Adama Mickiewicza w Poznaniu, Wydział Filologii Polskiej i Klasycznej. Poznań 27. 02. 2013 [dok. niepubl.].

Uchwała (2012). Uchwała Zarządu Głównego Towarzystwa Kultury Języka. Forum Akademickie [27.02.2015], https://forumakademickie.pl/aktualnosci/2012/2/28/1153/uchwala-zarzadu-glownego-towarzystwa-kultury-jezyka-w-sprawie-ochrony-polskiego-jezyka-naukowego/

Ustawa (1999). Ustawa z dnia 7 października o języku polskim. Dz. U., Nr 90, poz. 999.

Ustawa (2010). Ustawa z dnia 30 kwietnia 2010 o Narodowym Centrum Nauki. Dz. U., Nr 96, poz. 617.

UW (2013). Stanowisko Rady Wydziału Historycznego Uniwersytetu Warszawskiego w sprawie kompleksowej oceny jednostki naukowej za lata 2009-2012 [27.02.2015], www.wh.uw.edu.pl/ zalki/upload2044.doc

Wiertlewski, S. (2011). Wielopodmiotowość współczesnej polskiej polityki językowej. Język. Komunikacja. Informacja, 6, 99-107.

Zarządzenie (2012). Zarządzenie Ministra Nauki i Szkolnictwa Wyższego z dnia 28 marca 2012 w sprawie powołania Zespołu specjalistycznego do oceny czasopism naukowych dla potrzeb przyszłej oceny parametrycznej i sporządzenia wykazu wybranych czasopism naukowych. Dziennik Urzędowy MNiSW poz. 28. 


\title{
Linguistic Aspects of Polish Academic Policy. Between Locality and Globalization of Information
}

\begin{abstract}
Purpose/thesis: The purpose of this paper is to prove the thesis that a significant influence on Polish language policy is exerted by the institutions which create academic policy.

Approach/methods: The principles of official Polish language policy, as expressed in the Polish Constitution and in the Act on Polish language, are confronted with the legal instruments produced by the institutions responsible for Polish academic policy.

Results and conclusions: The assumptions behind the academic policy show clear lack of concern for the adherence to the spirit of the Act on Polish language, even though the policy complies with the letter of the law. The spirit of that Act - expressed above all in its ceremonial preamble - stands in contradiction to the pressure which is placed on academics in Poland to publish in foreign languages, primarily English.

Originality/value: There have been few publications to date, in the literature on either information science or linguistics, addressing the question of the influence exerted on language policy by the institutions responsible for academic policy.
\end{abstract}

\section{Keywords}

Language planning. Language policy. Academic policy. Information science.

Dr hab. PIOTR NOWAK jest profesorem na Uniwersytecie im. A. Mickiewicza w Poznaniu, kierownikiem Zaktadu Infolingwistyki w Instytucie Językoznawstwa LAM; specjalizuje się w historii ruchu wydawniczego, nauce o informacji oraz wybranych aspektach polityki językowej; autor stu kilkudziesięciu publikacji, w tym m.in. następujacych ksiażek: Wybrane problemy efektywności polskich czasopism naukowych $z$ dziedziny humanistyki (Poznań 2000), Bibliometria. Webometria. Podstawy. Wybrane zastosowania (wyd. 1 Poznan 2006, wyd. 2 Poznań 2008), Cenzura wobec rynku książi. Wojewódzki Urzad Kontroli Prasy, Publikacji $i$ Widowisk w Poznaniu w latach 1946-1955 (Poznań 2012).

Kontakt $z$ autorem:

pnowak@amu.edu.pl

Instytut Językoznawstwa

Uniwersytet im. Adama Mickiewicza w Poznaniu

al. Niepodlegtości 4

61-874 Poznań 